\title{
ANALISA PENGARUH KADAR LUMPUR PADA PASIR TERHADAP KUAT TEKAN BETON (PASIR SEMAYA DAN PASIR SIKASUR)
}

\author{
THE ANALYSIS INFLUENCE OF SLUDGE LEVEL IN SANDS \\ TOWARDS THE COMPRESSIVE STRENGTH OF CONCRETE \\ (SEMAYA SAND AND SIKASUR SAND)
}

\author{
Amir Lutfi Awwalu S', M. Agus Salim Al Fathoni ${ }^{2}$, Besty Afriandini ${ }^{3}$ \\ ${ }^{123}$ Program Studi S1 Teknik Sipil, Fakultas Teknik dan Sains \\ Universitas Muhammadiyah Purwokerto
}

\section{Informasi Artikel}

Dikirim, 8 September 2021

Direvisi, 17 Oktober 2021

Diterima, 3 Desember 2021

Korespondensi Penulis:

Amir Lutfi Awwalu Sa'ban Program Studi Teknik Sipil Universitas Muhammadiyah Purwokerto

JL. K.H. Ahmad Dahlan Purwokerto, 53182

Email:

amirlutfi388@gmail.com

\section{ABSTRAK}

Pasir Galian Semaya dan Pasir Galian Sikasur yang berada di Kabupaten Pemalang, Kecamatan Belik. Digunakan oleh masyarakat sebagai bahan campuran pembuatan beton. Kandungan lumpur yang berada di Pasir Galian Semaya dan Pasir Galian Sikasur berbeda-beda. Penelitian ini merupakan penelitian eksperimen untuk mengetahui kandungan lumpur pada pasir terhadap kuat tekan beton. Untuk mengetahui kuat tekan beton digunakan benda uji berbentuk silinder dengan diameter $15 \mathrm{~cm}$ x $30 \mathrm{~cm}$ dengan menggunakan variasi Pasir Galian Semaya dan Pasir Galian Sikasur dengan pengujian kuat tekan rencana 19,3 MPa pada umur beton 7 hari. Hasil penelitian menunjukan bahwa pasir Semaya memiliki kandungan lumpur sebesar 2,53\%, sedangkan pasir Sikasur memiliki kandungan lumpur sebesar $3,1 \%$.

Kata Kunci : Kata kunci dari artikel tersebut yang terdiri dari 3 sampai 5 kata dari yang paling penting dalam isi artikel, dipisahkan dengan koma.

\section{ABSTRACT}

Semaya and Sikasur sands, which located in Pemalang Regency, is used by the people as a mixture of concrete material. The mud contained in Semaya and Sikasur sand is different. This research is an experimental research to find out the mud content of sand in sand to concrete compressive strength. To find out the compressive strength of concrete it is used cylindrical specimens whit a diameter of $15 \mathrm{~cm} x 30 \mathrm{~cm}$ with the use of variations Semaya and Sikasur sands with a compressive strength testing plan of 19,3 MPa at the concrete age of 7 days. The results showed that Semaya sand had a mud contain of 2,53\%, while Sikasur sand had a mud contain of $3,1 \%$.

Keyword : Mud Level, Concrete, concrete Compressive Strength 


\section{PENDAHULUAN}

Menghadapi era globalisasi dunia, Indonesia yang diketahui sebagai salah satu Negara Berkembang dituntut untuk lebih kreatif serta memiliki keterampilan dalam bidang konstruksi, terutama teknologi pembuatan beton. Beton merupakan bahan bangunan yang telah umum digunakan untuk membuat rumah, jalan, jembatan, bendungan, gedung, dan lain-lain., hampir semua pekerjaan bangunan menggunakan beton. Perkembangan teknologi dari waktu ke waktu semakin pesat. Baik dari segi mutu, desain, dan metode pelaksanaannya. Dibandingkan dengan baja dan kayu, beton lebih sering dipilih karena relatif lebih kuat terhadap kuat tekan,mudah dalam pekerjaannya dan perawatannya, mudah dibentuk sesuai kebutuhan, tahan terhadap cuaca, tahan terhadap korosi dan api.

Beton merupakan campuran semen Portland atau semen hidrolis lainnya, agregat halus, agregat kasar, dan air, dengan atau tanpa bahan tambahan (admixture). (SNI, 284:2013). Beton terdiri dari 60-80\% agregat halus dan agregat kasar untuk mengisi volume beton, oleh karena itu agregat sangat mempengaruhi mutu beton. Agregat halus yang ada di pasaran sangat beragam jenisnya, ada yang berasal dari galian, sungai, dan gunung. Dari banyaknya jenis agregat halus masih banyak ditemukan agregat halus yang tidak memenuhi standard ketentuan yang berlaku, khususnya kadar lumpur pada pasir.

Pasir yang biasanya diambil dari galian kemungkinan pasir besar pasir itu sangat kotor, misalkan bercampur dengan lumpur maupun zat organik lainnya. Pasir sebagai agregat halus dalam adukan beton tidak diperbolehkan terlalu banyak mengandung zat organik karena akan mengakibatkan penurunan kekuatan beton yang dihasilkan. Hal ini juga terjadi apabila jumlah lumpur yang terlalu banyak. Kandungan lumpur pada pasir cenderung menghambat hidrasi pada beton ( persenyawaan semen dengan air). Keadaan akan bertambah buruk apabila lumpur mengandung lapisan yang menyelimuti agregat sehingga mencegah terjadinya adhesi semen. Adanya lumpur pada pasir ditandai dengan bertambahnya volume ketika agregat direndam air. Pasir yang digunakan sebagai agregat untuk pembuatan beton harus memiliki kandungan lumpur $<5 \%$ dari berat kering.

Pasir Semaya dan pasir Sikasur terletak di Kabupaten Pemalang dan berada di Kecamatan Belik dan Randudongkal. Pasir ini sering digunakan warga setempat bahkan dari kecamatan lainnya untuk bahan campuran beton. Selain harganya yang relatif murah juga mudah untuk mendapatkanya, namun banyak warga yang belum mengetahui tentang bagus atau jeleknya pasir tersebut mereka hanya melihat secara fisiknya saja tanpa mengetahui kandungan pasir tersebut. Berbagai penelitian telah dilakukan. Tujuannya adalah demi memperoleh mutu dan kualitas beton yang lebih baik. Baik dari segi kuat tekan (Comperssive strength), kemampuan pengerjaan (workability), kemampuan pengaliran (flowability), serta keawetannya (durability). Mengingat dengan pentingnya pengaruh agregat halus terhadap kuat tekan beton, oleh karena itu dalam penelitian ini akan membahas kandungan lumpur pada pasir. Penelitian yang pernah dilakukan diantaranya dengan mengukur pengaruh lumpur pada agregat halus, pada kuat tekan beton.

\section{METODE PENELITIAN}

Jenis penelitian yang digunakan adalah penelitian experimen tentang analisis kadar lumpur pada pasir terhadap kuat tekan beton dengan bahan pasir galian Semaya dan pasir galian Sikasur sebagai campuran agregat halus. Metode yang digunakan untuk mengetahui hasil dari penelitian melalui beberapa tahap yaitu sebagai berikut:

\subsection{Tahap persiapan}

Menyiapkan bahan dan menyiapkan peralatan yang digunakan untuk penelitian. Dengan bahan pasir galian Semaya dan pasir galian Sikasur sebagai campuran agregat halus, dan peralatan yang meliputi timbangan, ayakan, molen, Compression testing machine, Kerucut Abram's, dan lain-lain.

\subsection{Tahap pemeriksaan}

Pada tahap ini dilakukan pengujian material yang akan digunakan pada penelitian meliputi pengujian gradasi agregat halus, pengujian kadar lumpur, pengujian berat jenis dan penyerapan, dan pengujian keausan agregat kasar. Dalam pengujian bahan ini dapat diketahui apakah bahan yang akan digunakan pada penelitian memenuhi syarat atau tidak bila digunakan sebagai rancangan campur (Mix Design beton).

\subsection{Tahap pembuatan benda uji}

Pada tahap ini langkah yang harus dilakukan adalah membuat rancangan campuran beton dengan menggunakan metode SNI Perancangan Beton 03-2834-2000. Menetapkan campuran adukan beton, melakukan penakaran bahan-bahan material yang akan digunakan sesuai perencanaan campuran beton, pembuatan adukan beton dengan menggunakan mesin pengaduk (molen), pengujian nilai slump, penuangan adukan ke dalam cetakan, pemadatan beton dalam cetakan, perataan dalam cetakan. 


\subsection{Tahap perawatan}

Perawatan beton dilakukan pada saat beton sudah mulai mengeras. Perawatan ini dilakukan dengan cara direndam dalam air selama 3 hari kemudian di angina-anginkan sebelum diuji Setelah itu dilakukan pengujian kuat tekan beton.

\subsection{Tahap pengujian}

Pada tahap ini dilakukan pengujian karakteristik mekanik dari beton berupa uji kuat tekan beton dengan prosedur pengujian dan penghitungan mengikuti standar SNI dan ASTM.

Metode berikutnya pengumpulan data dengan menggunakan dokumen yang terdiri dari data hasil, foto, video proses dilakukannya penelitian.

\section{HASIL DAN PEMBAHASAN}

\subsection{Pengujian Agregat Halus}

Pengujian terhadap agregat halus berupa pasir yang berasal dari pasir galian Semaya dan pasir galian Sikasur dalam penelitian ini meliputi :

1. Pengujian Gradasi Agregat Halus

2. Pengujian Kadar Lumpur Agregat Halus

3. Pengujian Berat Jenis dan Penyerapan Air Agregat Halus

Adapun hasil dari pengujian agregat halus yaitu sebagai berikut:

\section{Pengujian Gradasi Agregat Halus}

\section{a. Pasir Galian Semaya}

Tabel 1. Hasil Pengujian Gradasi Agregat Halus Pasir Galian Semaya

\begin{tabular}{cccccccc}
\hline No. & $\begin{array}{c}\text { Diameter } \\
\text { Ayakan } \\
(\mathbf{m m})\end{array}$ & $\begin{array}{c}\text { Berat } \\
\text { Tertahan } \\
(\mathbf{g r a m})\end{array}$ & $\begin{array}{c}\text { Berat } \\
\text { Tertahan } \\
(\boldsymbol{\%})\end{array}$ & $\begin{array}{c}\text { Persentase } \\
\text { Kumulatif } \\
(\boldsymbol{\%})\end{array}$ & $\begin{array}{c}\text { Berat } \\
\text { Lolos } \\
(\mathbf{g r a m})\end{array}$ & $\begin{array}{c}\text { Kelolosan } \\
(\boldsymbol{\%})\end{array}$ & $\begin{array}{c}\text { SNI } \\
\text { Zona 2 } \\
(\boldsymbol{\%})\end{array}$ \\
\hline 1 & 9,5 & 0 & 0 & 0 & 1000 & 100 & $100-100$ \\
2 & 4,75 & 0 & 0 & 0 & 1000 & 100 & $90-100$ \\
3 & 2,36 & 139,1 & 13,91 & 13,91 & 860,9 & 86,09 & $75-100$ \\
4 & 1,18 & 147,7 & 14,77 & 28,68 & 713,2 & 71,32 & $55-90$ \\
5 & 0,6 & 197,0 & 19,70 & 48,38 & 516,2 & 51,62 & $35-59$ \\
6 & 0,3 & 217,2 & 21,72 & 70,10 & 299,0 & 29,90 & $8-30$ \\
7 & 0,15 & 223,0 & 22,30 & 92,40 & 76,0 & 7,60 & $0-10$ \\
8 & Pan & 76,0 & 7,60 & 100 & 0 & 0 & 0 \\
\hline
\end{tabular}

Sumber : Analisis, 2021.

$$
\begin{aligned}
& \mathrm{FM}=\frac{\sum \text { persen kumulatif tertahan mulai dari saringan } 0,15 \mathrm{~mm}}{100} \\
& =\frac{100+86,09+71,32+51,62+29,90+7,60}{100} \\
& =\frac{346,53}{100}=3,46 \%
\end{aligned}
$$

Dari hasil perhitungan diatas maka diketahui Modulus Halus sebesar 3,46\%. Nilai ini masih dalam batas yang diizinkan yaitu 1,5 - 3,8\% (Menurut SK SNI S-04-1989-F). Dan sesuai dengan hasil pemeriksaan gradasi pasir maka pasir yang digunakan dalam penelitian ini memenuhi syarat dan masuk dalam gradasi zona 2.

\section{b. Pasir Galian Sikasur}

Tabel 2. Hasil Pengujian Gradasi Agregat Halus Pasir Galian Sikasur

\begin{tabular}{cccccccc}
\hline No. & $\begin{array}{c}\text { Diameter } \\
\text { Ayakan } \\
(\mathbf{m m})\end{array}$ & $\begin{array}{c}\text { Berat } \\
\text { Tertahan } \\
(\text { gram })\end{array}$ & $\begin{array}{c}\text { Berat } \\
\text { Tertahan } \\
(\boldsymbol{\%})\end{array}$ & $\begin{array}{c}\text { Persentase } \\
\text { Kumulatif }\end{array}$ & $\begin{array}{c}\text { Berat } \\
\text { Lolos } \\
(\boldsymbol{g r a m})\end{array}$ & $\begin{array}{c}\text { Kelolosan } \\
\text { Zona 1 } \\
(\boldsymbol{\%})\end{array}$ \\
\hline 1 & 9,5 & 0 & 0 & 0 & 1000 & 100 & $100-100$ \\
2 & 4,75 & 1.7 & 0.17 & 0.17 & 998.3 & 99.83 & $90-100$ \\
3 & 2,36 & 222.9 & 22.29 & 22.46 & 775.4 & 77.54 & $60-95$
\end{tabular}

Analisa Pengaruh Kadar Lumpur Pada Pasir Terhadap Kuat Tekan Beton (Pasir Semaya Dan Pasir Sikasur) 


\begin{tabular}{rccccccc}
\hline & & & & & & \\
4 & 1,18 & 279.2 & 27.92 & 50.38 & 496.2 & 49.62 & $30-70$ \\
5 & 0,6 & 275.4 & 27.54 & 77.92 & 220.8 & 22.0 & $15-34$ \\
6 & 0,3 & 141.5 & 14.15 & 92.07 & 79.3 & 7.93 & $5-20$ \\
7 & 0,15 & 69.0 & 6.90 & 98.7 & 10.3 & 1.03 & $0-10$ \\
8 & Pan & 10.3 & 1.03 & 100 & 0 & 0 & 0 \\
\hline \multicolumn{2}{l}{ Sumber: Analisis, 2021.} & 1000 & 1000 & 100 & & &
\end{tabular}

$$
\begin{aligned}
\mathrm{FM}= & \frac{\sum \text { persen kumulatif tertahan mulai dari saringan } 0,15 \mathrm{~mm}}{100} \\
& =\frac{99,83+77,54+49,62+22,0+7,93+1,03}{100} \\
& =\frac{257,95}{100}=2,57 \%
\end{aligned}
$$

Dari hasil perhitungan diatas maka diketahui Modulus Halus sebesar 2,57\%. Nilai ini masih dalam batas yang diizinkan yaitu 1,5 - 3,8\% (Menurut SK SNI S-04-1989-F). Dan sesuai dengan hasil pemeriksaan gradasi pasir maka pasir yang digunakan dalam penelitian ini memenuhi syarat dan masuk dalam gradasi zona 1.

\section{Pengujian Kadar Lumpur Agregat Halus}

a. Pasir Galian Semaya

Tabel 3. Hasil Pemeriksaan Kadar Lumpur Pada Pasir

\begin{tabular}{cccc}
\hline & Satuan & I & II \\
\hline Berat Kering Oven Sebelum Dicuci (a) & gram & 200 & 200 \\
Berat Kering Oven Setelah Dicuci (b) & gram & 194,5 & 195,4 \\
Kadar Lumpur & $\%$ & 2.75 & 2,3 \\
Rata-Rata & $\%$ & \multicolumn{2}{c}{2.53} \\
\hline Sumber : Analisis, 2021 & &
\end{tabular}

Dari hasil pemeriksaan diatas maka dapat di hitung kadar lumpuragregat halus dengan rumus berikut :

$$
\begin{aligned}
& \frac{(a)-(b)}{(a)} \times 100 \%=\frac{200-194,5}{200} \times 100 \%=2,75 \\
& \frac{(a)-(b)}{(a)} \times 100 \%=\frac{200-195,4}{200} \times 100 \%=2,3
\end{aligned}
$$

Hasil Rata-rata $=\frac{\text { hasil benda uji } 1+\text { hasil benda uji } 2}{2}$

$$
\begin{aligned}
& =\frac{2,75+2,3}{2} \\
& =2,53 \%<5 \%
\end{aligned}
$$

Kadar lumpur rata-rata yang diperoleh sebesar 2,53\%. Dari hasil diatas maka menunjukan bahwa pasir tersebut memenuhi syarat sebagai bahanpengisi beton sesuai dengan SK SNI S-04-1998-F,1989, karena kadar lumpur tersebut kurang dari $5 \%$.

\section{b. Pasir Galian Sikasur}

Tabel 4. Hasil Pemeriksaan Kadar Lumpur Pada Pasir

\begin{tabular}{cccc}
\hline & Satuan & I & II \\
\hline Berat Kering Oven Sebelum Dicuci (a) & gram & 200 & 200 \\
Berat Kering Oven Setelah Dicuci (b) & gram & 193,6 & 194 \\
Kadar Lumpur & $\%$ & 3,2 & 3 \\
Rata-Rata & $\%$ & & 3,1 \\
\hline Surat & &
\end{tabular}


Dari hasil pemeriksaan diatas maka dapat di hitung kadar lumpuragregat halus dengan rumus berikut :

$$
\begin{aligned}
& \qquad \begin{array}{l}
\frac{(a)-(b)}{(a)} \times 100 \%=\frac{200-193,6}{200} \times 100 \%=3,2 \\
\frac{(a)-(b)}{(a)} \times 100 \%=\frac{200-194}{200} \times 100 \%=3 \\
\text { Hasil Rata-rata } \quad=\frac{\text { hasil benda uji } 1+\text { hasil benda uji } 2}{2} \\
=\frac{3,2+3}{2} \\
=3,1 \%<5 \%
\end{array}
\end{aligned}
$$

Kadar lumpur rata-rata yang diperoleh sebesar 3,1\%. Dari hasil diatas maka menunjukan bahwa pasir tersebut memenuhi syarat sebagai bahanpengisi beton sesuai dengan SK SNI S-04-1998-F,1989, karena kadar

\begin{tabular}{|c|c|c|c|}
\hline No. & Uraian & & $\begin{array}{c}\text { Sampel (1) } \\
\text { (gram) }\end{array}$ \\
\hline 1 & Berat pasir SSD & (A) & 500.0 \\
\hline 2 & Berat tabung + air & (B) & 664.0 \\
\hline 3 & Berat tabung + pasir + air & (C) & 955.0 \\
\hline 4 & Berat pasir kering oven & (D) & 453.3 \\
\hline \multicolumn{3}{|c|}{$=\mathrm{D} /(\mathrm{B}+\mathrm{A}-\mathrm{C})$} & 2.17 \\
\hline \multicolumn{3}{|c|}{ Berat jenis atas dasar SSD } & 2.39 \\
\hline \multicolumn{3}{|c|}{$=\mathrm{D} /(\mathrm{B}+\mathrm{D}-\mathrm{C})$} & 2.79 \\
\hline $\begin{array}{l}\text { Penyera } \\
=(A-D) / 1\end{array}$ & & & $10.3 \%$ \\
\hline
\end{tabular}
lumpur tersebut kurang dari $5 \%$.

\section{Pengujian Berat Jenis dan Penyerapan Air Agregat Halus}

a. Pasir galian Semaya

\begin{tabular}{|c|c|c|c|}
\hline No. & \multicolumn{2}{|l|}{ Uraian } & $\begin{array}{c}\text { Sampel (1) } \\
(\text { gram })\end{array}$ \\
\hline 1 & Berat pasir SSD & (A) & 500.0 \\
\hline 2 & Berat tabung + air & (B) & 664.0 \\
\hline 3 & Berat tabung + pasir + air & (C) & 950 \\
\hline 4 & Berat pasir kering oven & (D) & 455,3 \\
\hline \multicolumn{3}{|c|}{ Berat jenis atas dasar kering oven } & 2.13 \\
\hline Berat jenis atas dasar SSD & \multicolumn{2}{|c|}{$=\mathrm{A} /(\mathrm{B}+\mathrm{A}-\mathrm{C})$} & 2.34 \\
\hline \multicolumn{2}{|c|}{$=\mathrm{D} /(\mathrm{B}+\mathrm{D}-\mathrm{C})$} & & 2.69 \\
\hline \multicolumn{3}{|c|}{ Penyerapan } & $9.82 \%$ \\
\hline
\end{tabular}

Tabel 5. Hasil Pengujian Berat Jenis dan Penyerapan Air Agregat Halus

\section{b. Pasir Galian Sikasur}

Tabel 6. Hasil Pengujian Berat Jenis dan Penyerapan Air Agregat Halus

\subsection{Pengujian Agregat Kasar}

Pengujian terhadap Agregat Kasar dalam penelitian ini meliputi :

1. Pengujian Gradasi Agregat Kasar.

2. Pengujian Berat Jenis dan Penyerapan Air Agregat Kasar.

Analisa Pengaruh Kadar Lumpur Pada Pasir Terhadap Kuat Tekan Beton (Pasir Semaya Dan Pasir Sikasur) 
3. Pengujian Keausan Agregat Kasar (Uji Los Angeles).

\section{Pengujian Gradasi Agregat Kasar}

Tabel 7. Hasil Pengujian Gradasi Agregat Kasar

\begin{tabular}{|c|c|c|c|c|c|c|c|}
\hline No. & $\begin{array}{c}\text { Diameter } \\
\text { Ayakan } \\
(\mathrm{mm}) \\
\end{array}$ & $\begin{array}{c}\text { Berat } \\
\text { Tertahan } \\
\text { (gram) }\end{array}$ & $\begin{array}{c}\text { Berat } \\
\text { Tertahan } \\
(\%)\end{array}$ & $\begin{array}{c}\text { Persentase } \\
\text { Kumulatif } \\
(\%)\end{array}$ & $\begin{array}{l}\text { Berat } \\
\text { Lolos } \\
\text { (gram) } \\
\end{array}$ & $\begin{array}{c}\text { Kelolosan } \\
(\%)\end{array}$ & $\begin{array}{c}\text { Syarat SNI } \\
(\text { maks 40mm) } \\
(\%)\end{array}$ \\
\hline 1 & 75 & 0 & 0 & 0 & 2000 & 100 & $100-100$ \\
\hline 2 & 37,5 & 94 & 4,7 & 4,7 & 1906 & 95,3 & $95-100$ \\
\hline 3 & 19 & 525 & 26,25 & 30,95 & 1381 & 69,05 & $35-70$ \\
\hline 4 & 9,5 & 966 & 48,3 & 79,25 & 415 & 20,75 & $10-40$ \\
\hline 5 & 4,75 & 405 & 20,25 & 99,5 & 10 & 0,5 & $0-5$ \\
\hline 6 & Pan & 10 & 0,5 & 100 & 0 & 0 & \\
\hline \multicolumn{2}{|c|}{ JUMLAH } & 2000 & 100 & & & & \\
\hline
\end{tabular}

Sumber : Analisis, 2021.

\section{Pengujian Berat Jenis dan Penyerapan Air Agregat Kasar}

Tabel 8. Hasil Pengujian Berat Jenis dan Penyerapan Air Agregat Kasar

\begin{tabular}{|c|c|c|c|}
\hline No. & Uraian & & $\begin{array}{c}\text { Sampel (1) } \\
\text { (gram) }\end{array}$ \\
\hline 1 & Berat agregat kering oven & (A) & 1000 \\
\hline 2 & Berat agregat kondisi SSD & (B) & 1023 \\
\hline 3 & Berat agregat dalam air & (C) & 642.7 \\
\hline \multicolumn{2}{|c|}{$=\mathrm{A} /(\mathrm{B}-\mathrm{C})$} & & 2,63 \\
\hline \multicolumn{2}{|c|}{ Berat jenis atas dasar SSD } & & 2,69 \\
\hline \multicolumn{2}{|c|}{ Berat Jenis Semu } & & 2,80 \\
\hline \multicolumn{2}{|c|}{ Penyerapan } & & $2,3 \%$ \\
\hline
\end{tabular}

\section{Pengujian Keausan Agregat Kasar}

Tabel 9. Hasil Pengujian Keausan Agregat Kasar

\begin{tabular}{|c|c|c|c|c|c|}
\hline \multirow{2}{*}{\multicolumn{2}{|c|}{$\begin{array}{c}\text { Gradasi Pemeriksaan } \\
\text { Saringan }\end{array}$}} & \multicolumn{4}{|c|}{ Gradasi A (Makas.40 mm) } \\
\hline & & & & & \\
\hline Lolos & Tertahan & $\begin{array}{c}\text { Berat } \\
\text { Sebelum } \\
\text { (a) } \\
\end{array}$ & $\begin{array}{c}\text { Berat } \\
\text { Sesudah } \\
\text { (b) }\end{array}$ & $\begin{array}{c}\text { Berat } \\
\text { Sebelum } \\
\text { (a) } \\
\end{array}$ & $\begin{array}{c}\text { Berat } \\
\text { Sesudah } \\
\text { (b) } \\
\end{array}$ \\
\hline $76,2\left(3^{\prime}\right)$ & $63,5(2$ 1/2") & & & & \\
\hline 63,5 (2 1/2") & $50,8\left(2^{\prime}\right)$ & & & & \\
\hline $50,8\left(2^{\prime}\right)$ & $37,5(1 \quad 1 / 2 ")$ & & & & \\
\hline 37,5 (1 1/2") & $25,4\left(1^{\prime}\right)$ & & & & \\
\hline $25,4\left(1^{\prime}\right)$ & $19,0(3 / 4 ")$ & 1250 & 88,2 & 1250 & 95,2 \\
\hline $19,0(3 / 4 ")$ & $12,5(1 / 2 ")$ & 1250 & 2152,6 & 1250 & 2310,8 \\
\hline $12,5(1 / 2 ")$ & $9,5\left(3 / 8^{\prime \prime}\right)$ & 1250 & 1062 & 1250 & 902 \\
\hline $9,5\left(3 / 8^{\prime}\right)$ & $6,3(1 / 4 ")$ & 1250 & 624,2 & 1250 & 627,5 \\
\hline $6,3\left(1 / 4^{\prime}\right)$ & No.4 & & 268,1 & & 263 \\
\hline No.4 & No.6 & & 16,5 & & 19,6 \\
\hline No.6 & No.8 & & 155,3 & & 153,5 \\
\hline Berat Tertahan Saringan & & & 38,1 & & 37,7 \\
\hline \multicolumn{6}{|l|}{ No. 12} \\
\hline Pan & & & 527,1 & & 525,2 \\
\hline Jumlah Berat & & 5000 & 4366,9 & 5000 & 4371,6 \\
\hline
\end{tabular}

CIVeng Vol.3, No.1, Januari 2022 : 1 10 


\begin{tabular}{ccc}
\cline { 2 - 3 } Keausan Agregat $\%$ & 12,662 & 12,568 \\
\hline Keausan Rata-rata \% & \multicolumn{1}{c}{$12,61 \%$} & \\
\hline Sumber : Analisis, 2021 &
\end{tabular}

Pada pengujian keausan agregat kasar mendapatkan nilai keausan sebesar 12,61 \%, nilai tersebut masih masuk kedalam batas maksimum yang diizinkan SNI yaitu sebesar $50 \%$.

\subsection{Perencanaan Mix Design Beton}

\section{Mix Design pasir galian Semaya}

Tabel 10. Perencanaan Mix Design Beton Normal Berbentuk Silinder

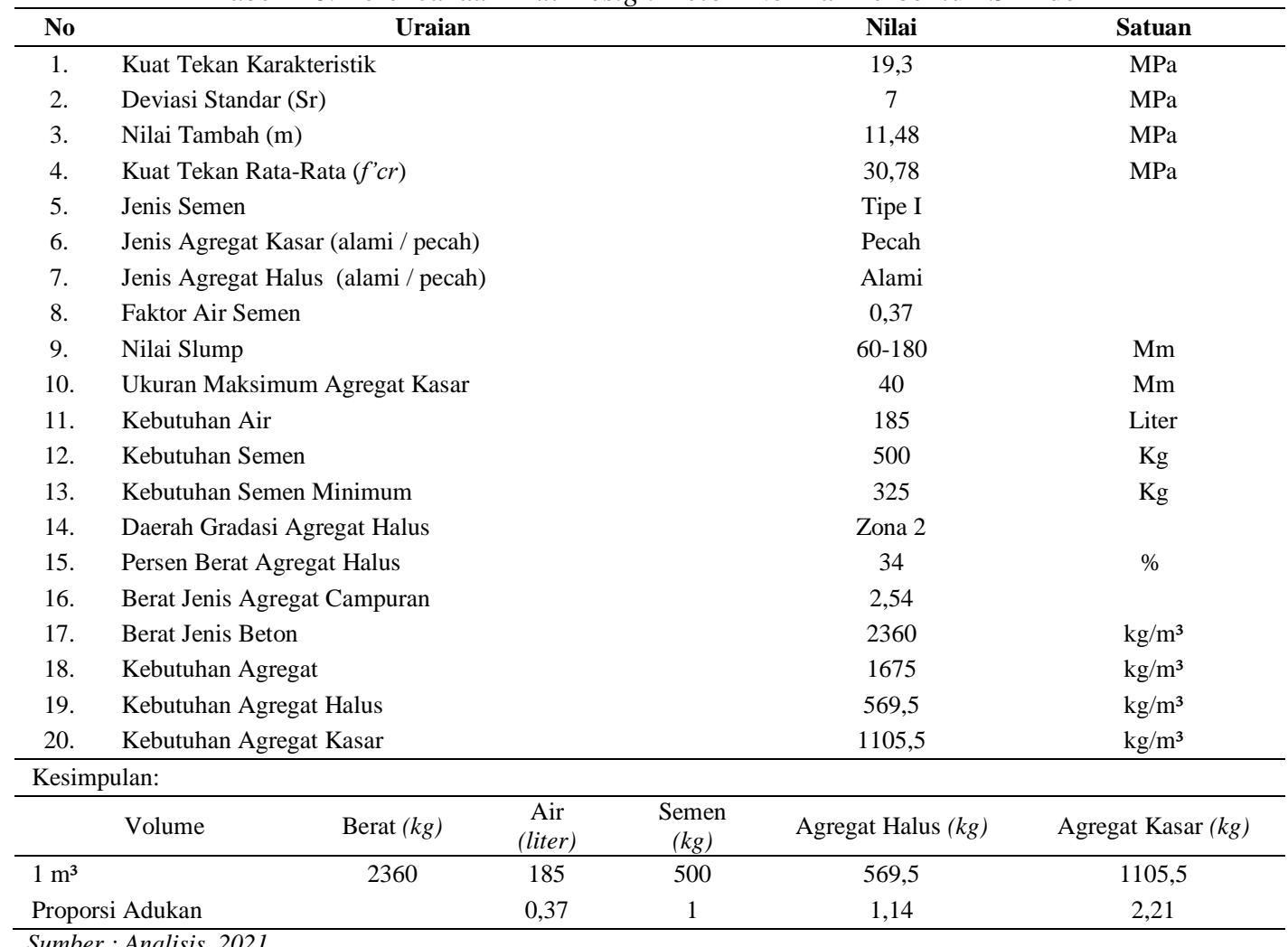

\section{Mix Desain pasir galian Sikasur}

Tabel 11. Perencanaan Mix Design Beton Normal Berbentuk Silinder

\begin{tabular}{|c|c|c|c|}
\hline No & Uraian & Nilai & Satuan \\
\hline 1. & Kuat Tekan Karakteristik & 19,3 & $\mathrm{MPa}$ \\
\hline 2. & Deviasi Standar (Sr) & 7 & $\mathrm{MPa}$ \\
\hline 3. & Nilai Tambah (m) & 11,48 & $\mathrm{MPa}$ \\
\hline 4. & Kuat Tekan Rata-Rata $\left(f^{\prime} c r\right)$ & 30,78 & $\mathrm{MPa}$ \\
\hline 5. & Jenis Semen & Tipe I & \\
\hline 6. & Jenis Agregat Kasar (alami / pecah) & Pecah & \\
\hline 7. & Jenis Agregat Halus (alami / pecah) & Alami & \\
\hline 8. & Faktor Air Semen & 0,37 & \\
\hline 9. & Nilai Slump & $60-180$ & $\mathrm{Mm}$ \\
\hline 10. & Ukuran Maksimum Agregat Kasar & 40 & $\mathrm{Mm}$ \\
\hline 11. & Kebutuhan Air & 185 & Liter \\
\hline 12. & Kebutuhan Semen & 500 & $\mathrm{Kg}$ \\
\hline 13. & Kebutuhan Semen Minimum & 325 & $\mathrm{Kg}$ \\
\hline 14. & Daerah Gradasi Agregat Halus & Zona 1 & \\
\hline 15. & Persen Berat Agregat Halus & 41,5 & $\%$ \\
\hline
\end{tabular}




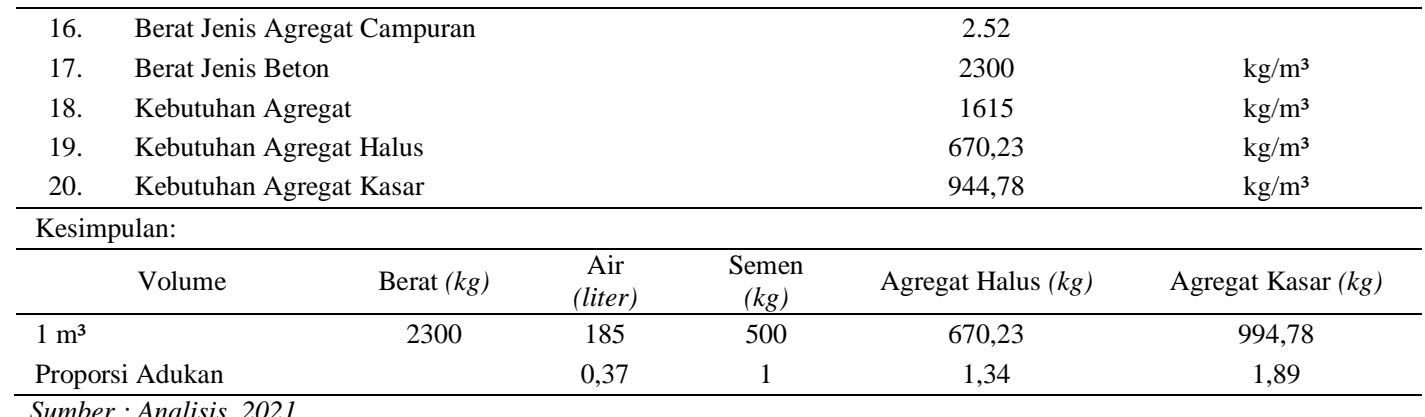

\subsection{Hasil Uji Slump}

Nilai Slump yang ditetapkan pada Mix Design untuk seluruh variasi pada penelitian ini yaitu antara 60 $180 \mathrm{~mm}$. Berikut adalah hasil uji slump dari pengujian 2 sampel yaitu sampel pasir galian Semaya dan pasir galian Sikasur:

Tabel 12. Hasil Uji Slump

\begin{tabular}{ccc}
\hline No & Nama Sampel & $\begin{array}{c}\text { Nilai Slump } \\
(\mathbf{m m})\end{array}$ \\
\hline 1 & Pasir Galian Semaya & 100 \\
2 & Pasir Galian Sikasur & 100 \\
\hline \multicolumn{2}{l}{ Sumber : Analisis, 2021}
\end{tabular}

\subsection{Hasil Pengujian Berat Sampel Beton Kering}

Setelah sampel beton menjalani proses curing selama umur beton yaitu 7 hari, kemudian sampel beton dikeringkan selama minimal 24 jam. Tetapi sebelum diuji kuat tekannya, beton terlebih dahulu ditimbang beratnya untuk mengetahui berat jenis dari beton yang telah dibuat. Berikut adalah hasil dari penimbangan berat beton :

Tabel 13. Hasil Uji Berat Beton

\begin{tabular}{|c|c|c|c|}
\hline Nama Sampel & $\begin{array}{c}\text { Berat Beton } \\
\text { Kering } \\
(\mathrm{kg}) \\
\end{array}$ & $\begin{array}{c}\text { Rata - Rata Berat } \\
\text { Beton Kering } \\
(\mathrm{kg}) \\
\end{array}$ & $\begin{array}{c}\text { Berat Beton Kering } \\
1 \mathbf{1 ~ m}^{\mathbf{3}} \\
(\mathrm{kg})\end{array}$ \\
\hline \multirow{3}{*}{ Pasir G. Semaya } & 12,450 & & \\
\hline & 12,720 & 12,605 & 2378,75 \\
\hline & 12,645 & & \\
\hline \multirow{3}{*}{ Pasir G.Sikasur } & 12,375 & & \\
\hline & 12,530 & 12,548 & 23661,17 \\
\hline & 12,710 & & \\
\hline
\end{tabular}

\subsection{Pengujian Kuat Tekan Beton}

Sampel beton yang telah ditimbang dan diketahui beratnya, selanjutnya yaitu menguji kuat tekan beton untuk masing-masing variasinya. Sebelumnya dilakukan proses capping menggunakan belerang pada permukaan atas sampel agar kuat tekan yang dihasilkan dapat merata ke seluruh permukaan atas sampel beton. Setelah proses capping selesai maka pengujian kuat tekan beton dapat dilakukan. Pengujian dilakukan di Laboratorium Teknologi Bahan Universitas Muhammadiyah Purwokerto.

\section{Hasil Pengujian Kuat Tekan Beton Silinder}

Beton berbentuk silinder memiliki diameter $15 \mathrm{~cm}$ dan tinggi $30 \mathrm{~cm}$. sampel beton yang digunakan menggunakan pasir galian Semaya dan pasir galian Sikasur masing-masing galian mengambil 3 sampel. Pengujian kuat tekan pada sampel beton berbentuk silinder yaitu :

Tabel 14. Hasil Uji Kuat Tekan Beton Silinder Pasir Semaya

\begin{tabular}{cccc}
\hline \multicolumn{5}{c}{ Perhitungan Kuat Tekan Sampel Pasir Semaya } \\
\hline \multicolumn{5}{c}{ Tanggal Pembuatan 26 Juli 2021 } \\
\hline Sampel & $\mathbf{1}$ & $\mathbf{2}$ & $\mathbf{3}$ \\
Pembacaan (Ton) & 23 & 28 & 29
\end{tabular}




\begin{tabular}{cccc} 
Berat Beton $(\mathrm{kg})$ & 12.450 & 12.720 & 12.645 \\
Luas Bidang $(\mathrm{mm} 2)$ & 17662,5 & 17662,5 & 17662,5 \\
Tanggal Uji & & 2 Agustus 2021 & \\
Umur & 7 hari & 7 hari & 7 hari \\
Kuat Tekan (N) & 225552,95 & 274586,20 & 284392,85 \\
Faktor Konversi (Bentuk) & 0,83 & 0,83 & 0,83 \\
Kuat Tekan (Mpa) & 12,77 & 15,55 & 16,10 \\
Rata-rata & & 14,81 & \\
Faktor Konversi (umur) & 0,65 & 0,65 & 0,65 \\
Konversi 28 hari (Mpa) & 19,65 & 23,92 & 24,77 \\
Rata-rata & & 22,78 & \\
Kuat Tekan K (kg/cm2) & 236,70 & 288,16 & 298,45 \\
\hline Sumber : Analisis, 2021 & &
\end{tabular}

Dari hasil perhitungan diatas dengan pembuatan 3 sampel maka didapat kuat tekan beton umur 7 hari sebesar 12,77 MPa, 15,55 MPa, 16,10 MPa. dan dikonversi ke umur 28 hari yaitu sebesar 19,65 MPa, 23,92 MPa, 24,77 MPa. Hasil kuat tekan tersebut sudah terpenuhi dengan kuat tekan rencana sebesar 19,3 MPa.

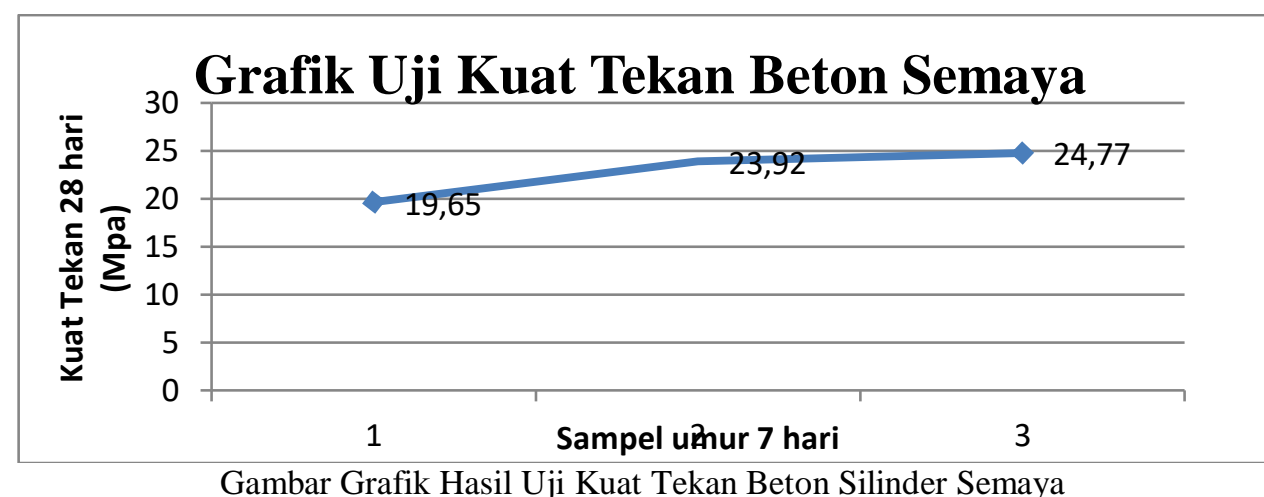

Gambar Grafik Hasil Uji Kuat Tekan Beton Silinder Semaya Sumber : Analisis, 2021

Tabel 15. Hasil Uji Kuat Tekan Beton Silinder Pasir Sikasur

\begin{tabular}{cccc}
\hline \multicolumn{4}{c}{ Perhitungan Kuat Tekan Sampel Pasir Sikasur } \\
\hline & Tanggal Pembuatan 26 Juli 2021 & $\mathbf{3}$ \\
Sampel & $\mathbf{1}$ & $\mathbf{2}$ & 27 \\
Pembacaan (Ton) & 29 & 32 & 12.710 \\
Berat Beton (kg) & 12.375 & 12.530 & 17662,5 \\
Luas Bidang (mm2) & 17662,5 & 17662,5 & \\
Tanggal Uji & & 2 Agustus 2021 & 7 hari \\
Umur & 7 hari & 7 hari & 264774,55 \\
Kuat Tekan (N) & 284392,85 & 313812,80 & 0,83 \\
Faktor Konversi (Bentuk) & 0,83 & 0,83 & 14,99 \\
Kuat Tekan (Mpa) & 16,10 & 17,77 & \\
Rata-rata & & 16,29 & 0,65 \\
Faktor Konversi (umur) & 0,65 & 0,65 & 23,06 \\
Konversi 28 hari (Mpa) & 24,77 & 27,33 & 277,86 \\
Rata-rata & & 25,06 &
\end{tabular}

Sumber : Analisis, 2021

Dari hasil perhitungan diatas dengan pembuatan 3 sampel maka didapat kuat tekan beton umur 7 hari sebesar 16,10 MPa, 17,77 MPa, 14,99 MPa. dan dikonversi ke umur 28 hari yaitu sebesar 24,77 MPa, 27,33 MPa, 23,06 MPa. Hasil kuat tekan tersebut sudah terpenuhi dengan kuat tekan rencana sebesar 19,3 MPa. 


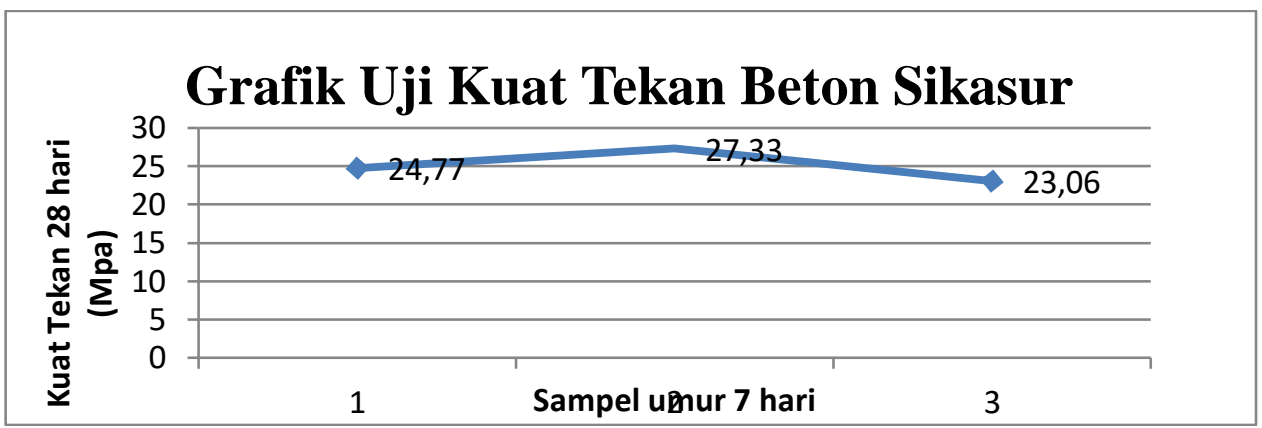

Gambar Grafik Hasil Uji Kuat Tekan Beton Silinder Sikasur

Sumber : Analisis, 2021

\subsection{Persentase Kuat Tekan Terhadap Kuat Tekan Rencana}

Tabel 16. Persentase Kuat Tekan Terhadap Kuat Tekan Rencana Setelah di Konversi ke 28 Hari

\begin{tabular}{ccc}
\hline Nama Sampel & Kuat Tekan & $\begin{array}{c}\text { Persentase Kuat Tekan Terhadap Kuat Tekan } \\
\text { Rencana }\end{array}$ \\
\hline Pasir Semaya & $19,65 \mathrm{MPa}$ & 0,35 \\
Pasir Semaya & $23,92 \mathrm{MPa}$ & 4,62 \\
Pasir Semaya & $24,77 \mathrm{MPa}$ & 5,47 \\
Pasir Sikasur & $24,77 \mathrm{MPa}$ & 5,47 \\
Pasir Sikasur & $27,33 \mathrm{MPa}$ & 8,03 \\
Pasir Sikasur & $23,06 \mathrm{MPa}$ & 3,76 \\
\hline Sumber : Analisis, 2021 & &
\end{tabular}

\section{Keterangan :}

Untuk beton umur 7 hari sebaiknya menggunakan factor air semen (fas) yang lebih rendah. Karena kadar air yang terlalu banyak akan mempengaruhi kuat tekan pada beton. Beton yang diuji cobakan adalah beton umur 7 hari dengan fas 0,37 dengan hasil kuat tekan seperti pada tabel 4.19 dan tabel 4.20.

\section{KESIMPULAN}

Berdasrkan penelitian dan analisis yang telah dilakukan mengenai kandungan kadar lumpur pada pasir galian Semaya dan pasir galian Sikasur terhadap kuat tekan beton, maka dapat di simpulkan sebagai berikut: 1. Pasir galian Semaya memiliki kandungan lumpur 2,53\% sedangkan pasir galian Sikasur memiliki kandungan lumpur $3,1 \%$.

2. Kuat tekan yang dihasilkan pada sampel silinder yang menggunakan pasir galian Semaya dan pasir galian Sikasur (masing-masing 3 sampel) setelah dikonversi ke umur 28 hari yaitu sebesar 19,65 MPa, 23,92 MPa, 24,77 $\mathrm{MPa}$, dan 24,77 MPa, 27,33 MPa, 23,06 MPa.

\section{DAFTAR PUSTAKA}

[1] Badan Standar Nasional. 2004. SNI-15-2049-2004. Tentang Semen Portland.

[2] Badan Standar Nasional. 1997. SNI-03-4141-1997. Pemeriksaan kadar lumpur agregat.

[3] Badan Standar Nasional. 2002. SNI-03-2847-2002. Tentang tata cara pembuatan rencana beton Nromal.

[4] Bambang Surendro \& AniWidiastuti. 2009.Pengaruh Variasi Gradasi Agregat Kasar Dan KadarLumpur Pada Pasir Terhadap Kuat Tekan Beton. Magelang: Fakultas Teknik Universitas Tidar.

[5] Chaniago. 2017. Campuran yang digunakan untuk campuran beton. http://repository.ump.ac.id

[6] Daryanto. 2008. Pengertian Pasir http://repository.upi.edu.

[7] Haris Septianto \& Ir. Suhendro Trinugroho, M.T. 2017. Pengaruh Kandungan Lumpur Pada Agregat Halus Terhadap Kuat Tekan Dan Kuat Tarik Belah Beton Normal. Surakarta: Fakultas Teknik Universitas Muhammadiyah Surakarta.

[8] Irawan dan Leonardo. 2010. Pengertian Tentang Beton Normal http://portaluniversitasquality.ac.id

[9] Muafif Hamdan. 2020. Analisis Kadar Lumpur Pada Pasir Terhadap Kuat Tekan Beton ( Pasir Serayu dan Pasir Logawa). Universitas Muhammadiyah Purwokerto.

[10] Satriani. 2019. Pengaruh Kadar Lumpur Terhadap Kuat Tekan Beton Normal. e-prosiding.poloban.ac.id

[11] SNI-03-1968-1990, Metode Pengujian Tentang Analisis Saringan Agregat Halus dan Kasar, Pusjatan-Balitbang PU.

[12] SNI 03-1969-2008. Metode Pengujian Berat Jenis dan Penyerapan Air Agregat Kasar. Pusjatan-Balitbang PU.

[13] SNI 03-2834-2000.Tata cara pembuatan rencana campuran beton normal, Badan Standarisasi Nasional. 